\title{
Evaluation of Little Millet based Intercropping Systems under Rainfed Conditions
}

\author{
P. Srilakshmi*, A. V. Nagavani, D. Subramanyam, \\ B. Ramana murthy and G. Karuna sagar
}

Department of Agronomy, S. V. Agricultural College, Tirupati, Andhra Pradesh 517 502, India

*Corresponding author

\begin{tabular}{|l|}
\hline K e y w o r d s \\
Little millet, \\
Intercropping \\
system, Grain yield \\
and test weight
\end{tabular}

\section{A B S T R A C T}

\section{Introduction}

Millets are a traditional staple food of the dryland regions of the world. The world production of millets was 26.7 million tonnes from an area of 33.6 million hectare whereas, in India millets are grown in an area of 17 million hectares with an annual production of 18 million tonnes and contribute 10 per cent to the country's food grain basket (Department of Agriculture Cooperation and Farmers Welfare, 2017). In recent years, there has been an increasing importance of millets as a substitute for major cereal crops in human diet.
Millets have the potentiality of contributing to increased food production both in developing and developed countries. On an average, millet grain contains $7-12 \%$ protein, $2-5 \%$ fat, $15-20 \%$ dietary fibre and 65-75\% carbohydrates. Millets have high proportion of non-starchy polysaccharides and dietary fibre which help in prevention of constipation, lowering of blood cholesterol, slow release of glucose into the blood stream during digestion, lower the incidence of cardiovascular diseases, duodenal ulcer and hyperglycemia (diabetes) are reported, among regular millet consumers. Little millet is one 
of the small millets gaining importance due to it's beneficial effects. Little millet is native to India and is called Indian millet. It is quick growing, short duration crop and can withstand both drought and water logging. It is an important catch crop in some tribal farms in India. Little millet is another reliable catch crop in view of its earliness and resistance to adverse agro-climatic conditions. The stover is a good fodder for cattle.

\section{Materials and Methods}

The field experiment was conducted during kharif, 2019 at dryland farm of S. V. Agricultural College, Tirupati campus of Acharya N. G. Ranga Agricultural University, Andhra Pradesh. The soil of experimental site was sandy loam having $0.24 \%$ organic carbon, $173.9 \mathrm{~kg} \mathrm{ha}^{-1}, 16.23 \mathrm{~kg} \mathrm{ha}^{-1}$ and 177.8 $\mathrm{kg} \mathrm{ha}{ }^{-1}$ of available $\mathrm{N}, \mathrm{P}_{2} \mathrm{O}_{5}$ and $\mathrm{K}_{2} \mathrm{O}$ respectively. A total rainfall received during the crop period was $712.8 \mathrm{~mm}$ received in 37 rainy days. The experiment was laid out in a randomized block design with nine treatments comprised of sole little millet $\left(\mathrm{T}_{1}\right)$, sole greengram $\left(T_{2}\right)$, sole cowpea $\left(T_{3}\right)$, sole cluster bean $\left(\mathrm{T}_{4}\right)$, sole groundnut $\left(\mathrm{T}_{5}\right)$, little millet + greengram $(4: 2)\left(\mathrm{T}_{6}\right)$, little millet + cowpea $(4: 2)\left(\mathrm{T}_{7}\right)$, little millet + cluster bean $(4: 2)$ $\left(\mathrm{T}_{8}\right)$ and little millet + groundnut $(4: 2)\left(\mathrm{T}_{9}\right)$ (Table 1). Little millet as well as intercrops were sown in lines, $30 \mathrm{~cm}$ apart by adopting all the standard package of practices. Both the sole and intercrops were fertilized separately as per the recommendation. The scheduled nitrogen was applied in two equal splits viz., first half at the time of sowing as basal and remaining half as top dressing at 30 DAS. Growth parameters viz., plant height, leaf area index, dry matter production and number of tillers $\mathrm{m}^{-2}$ were recorded at 20, 40, 60 DAS and at harvest. Yield attributes viz., number of panicles $^{-2}$, panicle weight and test weight were recorded from the net plot. Grain and straw yield were recorded based on the yield obtained from net plot.

\section{Results and Discussion}

Growth parameters like plant height, leaf area index and dry matter production was significantly affected by intercropping. Sole little millet $\left(\mathrm{T}_{1}\right)$ recorded higher plant height, leaf area index and dry matter production. Among the intercropping systems tried, plant height of little millet was found to be higher at all the stages under the treatment, little millet + greengram $(4: 2)\left(\mathrm{T}_{6}\right)$ followed by little millet + cowpea $(4: 2)\left(\mathrm{T}_{7}\right)$ (Table 1$)$. Similar results were also obtained by Kumar et al., (2009), Choudhary et al., (2012), Tripathi and kushwaha (2013), Pradhan et al., (2014) and Manjunath and Salakinkop (2017).

Table.1 Effect of intercropping systems on growth parameters of little millet

\begin{tabular}{|c|c|c|c|}
\hline Treatments & Plant height (cm) & Leaf area index & Dry matter production $\left(\mathrm{kg} \mathrm{ha}^{-1}\right)$ \\
\hline $\mathbf{T}_{1}$ : Sole little millet & 124 & 2.50 & 3021 \\
\hline $\mathbf{T}_{2}$ : Sole greengram & - & - & - \\
\hline $\mathbf{T}_{3:}$ Sole cowpea & - & - & - \\
\hline $\mathbf{T}_{4}$ : Sole cluster bean & - & - & - \\
\hline $\mathbf{T}_{5}$ : Sole groundnut & - & - & - \\
\hline$T_{6:}$ Little millet + Greengram (4:2) & 122 & 2.43 & 2829 \\
\hline $\mathbf{T}_{7}$ : Little millet + Cowpea $(4: 2)$ & 119 & 2.36 & 2799 \\
\hline $\mathbf{T}_{8}$ : Little millet + Cluster bean (4:2) & 108 & 2.23 & 2510 \\
\hline $\mathbf{T}_{9}$ : Little millet + Groundnut $(4: 2)$ & 117 & 2.28 & 2544 \\
\hline SEm \pm & 3.5 & 0.07 & 59 \\
\hline $\mathrm{CD}(\mathrm{P}=\mathbf{0 . 0 5})$ & 10 & 0.21 & 178 \\
\hline
\end{tabular}


Table.2 Effect of intercropping systems on yield attributes of little millet

\begin{tabular}{|c|c|c|c|c|c|}
\hline Treatments & $\begin{array}{c}\text { No. of } \\
\text { panicles } \mathbf{m}^{-2}\end{array}$ & $\begin{array}{c}\text { Panicle } \\
\text { weight (g) }\end{array}$ & $\begin{array}{c}\text { Test weight } \\
\text { (g) }\end{array}$ & $\begin{array}{l}\text { Grain yield } \\
\left(\mathrm{kg} \mathrm{ha}^{-1}\right)\end{array}$ & $\begin{array}{c}\text { Straw yield } \\
\left(\mathrm{kg} \mathrm{ha}^{-1}\right)\end{array}$ \\
\hline $\mathbf{T}_{1}$ : Sole little millet & 153 & 2.94 & 2.64 & 1538 & 1903 \\
\hline $\mathbf{T}_{2}$ : Sole greengram & - & - & - & - & - \\
\hline$T_{3}$ : Sole cowpea & - & - & - & - & - \\
\hline$T_{4}$ : Sole cluster bean & - & - & - & - & - \\
\hline $\mathbf{T}_{5}$ : Sole groundnut & - & - & - & - & - \\
\hline$T_{6:}$ Little millet + Greengram $(4: 2)$ & 142 & 2.87 & 2.61 & 1302 & 1584 \\
\hline 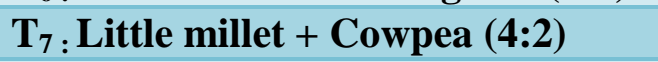 & 137 & 2.83 & 2.59 & 1196 & 1465 \\
\hline$T_{8}$ : Little millet + Cluster bean $(4: 2)$ & 129 & 2.78 & 2.55 & 1128 & 1349 \\
\hline $\mathbf{T}_{9:}$ Little millet + Groundnut (4:2) & 135 & 2.81 & 2.57 & 1152 & 1434 \\
\hline SEm \pm & 5.0 & 0.03 & 0.02 & 52.5 & 59.8 \\
\hline $\mathrm{CD}(\mathrm{P}=\mathbf{0 . 0 5})$ & 15 & 0.09 & NS & 157 & 179 \\
\hline
\end{tabular}

The yielding ability of a crop is reflected through its yield attributing characters. The yield attributes of little millet like number of panicles $\mathrm{m}^{-2}$, panicle weight and test weight were found to be increased when intercropped with greengram (4:2) $\left(\mathrm{T}_{6}\right)$ (Table 2). This might be due to development of better complementary relationship and nonrenewable resources like water, nutrients and incoming sunlight. Similar pattern was observed by Kumar et al., (2009) and Ansari et al., (2011).

Grain and straw yield of little millet was significantly affected due to the different intercropping systems. Higher values of grain and straw yields were realized with sole little millet $\left(\mathrm{T}_{1}\right)$. Among the intercropping systems, little millet + greengram $\left(T_{6}\right)$ recorded significantly higher grain and straw yield of little millet followed by little millet + cowpea $\left(\mathrm{T}_{7}\right)$, while little millet + cluster bean $\left(\mathrm{T}_{8}\right)$ registered lower grain and straw yield. The results are corroborating with the findings of Kumar et al., (2009) and Choudhary et al., (2012).

\section{References}

Ansari, M.A., Rana, K.S., Rana, D.S and
Kumar, A. 2012. Effect of an antitranspirant as growth suppressant and nutrient management on growth, productivity and quality of pearlmillet (Pennisetum glacum L.) and pigeonpea (Cajanus cajan) intercropping system under rainfed conditions. Indian Journal of Agronomy. 57(4): 30-35.

Choudhary, R., Dodia, I.N., Choudhary, R and Golada, S.L. 2012. Effect of pearlmillet-based pulses intercropping systems in rainfed conditions. International Journal of Forestry and Crop Improvement. 3(2): 112-115.

Department of Agriculture Cooperation and Farmers Welfare, 2017. Ministry of Agriculture, cooperation and farmers welfare.

Kumar, B.H.P., Halikatti, S.I and Ningaru, B.T. 2009. Sustainable intercrop association of pigeonpea (Cajanus cajan) in little millet (Panicum sumatrense L.). Karnataka Journal of Agricultural Sciences. 22(4): 887888.

Manjunath, M.G and Salakinkop, S.R. 2017. Growth and yield of soybean and millets in intercropping systems. Journal of Farm Sciences. 30(3): 349-353. 
Panse, V.G and Sukhatme, P.V. 1985. Statistical Methods for Agricultural Workers. Indian Council of Agricultural Research, New Delhi. pp. 100-174.

Pradhan, A., Rajput, A.S and Thakur, A. 2014. Yield and economics of finger millet (Eleusine coracana L. Gaertn) intercropping system. International Journal of Current Microbiology and Applied Sciences. 3(1): 626-629.
Tripathi, A.K and Kushwaha, H.S. 2013. Performance of pearlmillet (Pennisetum glaucum L.) intercropped with pigeonpea (Cajanus cajan) under varying fertility levels in the rainfed environment of Bundelkhand region. Annals of Agricultural Research. New Series. 34(1): 36-43.

\section{How to cite this article:}

Srilakshmi, P., A. V. Nagavani, D. Subramanyam, B. Ramana murthy and Karuna sagar, G. 2020. Evaluation of Little Millet based Intercropping Systems under Rainfed Conditions. Int.J.Curr.Microbiol.App.Sci. 9(07): 2312-2315. doi: https://doi.org/10.20546/ijcmas.2020.907.269 